\title{
Determination of zearalenone in raw milk from different provinces of Ecuador
}

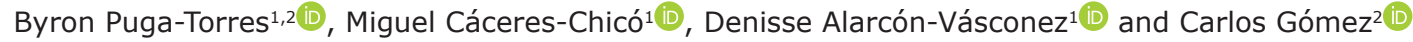

1. Laboratorio de Control de Calidad de Leches, Facultad de Medicina Veterinaria y Zootecnia, Universidad Central del Ecuador, Quito, Ecuador; 2. Doctorado en Ciencia Animal, Facultad de Zootecnia y Escuela de Postgrado, Universidad Nacional Agraria La Molina, Lima-Perú.

Corresponding author: Byron Puga-Torres, e-mail: bpuga@uce.edu.ec

Co-authors: MC: macaceresc@uce.edu.ec, DA: maritd-1993@hotmail.com, CG: cagomez@lamolina.edu.pe Received: 23-03-2021, Accepted: 30-06-2021, Published online: 09-08-2021

doi: www.doi.org/10.14202/vetworld.2021.2048-2054 How to cite this article: Puga-Torres B, Cáceres-Chicó M, Alarcón-Vásconez D, Gómez C (2021) Determination of zearalenone in raw milk from different provinces of Ecuador, Veterinary World, 14(8): 2048-2054.

\begin{abstract}
Background and Aim: Zearalenone (ZEA) is a mycotoxin from the fungus Fusarium. ZEA can adopt a similar configuration to $17 \beta$-estradiol and other natural estrogens. Problems in the reproductive function of humans and animals have been reported for ZEA and its metabolites. This study aimed to determine ZEA in raw milk produced in representative milk production areas in Ecuador.
\end{abstract}

Materials and Methods: A total of 209 samples were obtained in April and November 2019 (rainy season) and June and August 2019 (dry season). A competitive enzyme-linked immunosorbent assay technique was used to detect ZEA concentrations.

Results: ZEA was determined in $99.5 \%$ (208 of 209) of the samples; however, all samples were below the maximum limits allowed $(0.03-1 \mathrm{mg} / \mathrm{L})$ in food for direct human consumption according to the Food and Agriculture Organization and European legislations. The mean (range) concentration was $0.0015(0-0.0102) \mathrm{mg} / \mathrm{L}$. The results did not vary significantly $(\mathrm{p} \geq 0.05)$ by cantons, provinces, weather, climate regions, types of producers, and production systems according to Wilcoxon and Kruskal-Wallis non-parametric tests. There were significant differences only between the months under study ( $\mathrm{p} \leq 0.05$ ).

Conclusion: ZEA in raw milk from Ecuador does not represent a threat to public health. However, it is recommended to continue analyzing ZEA due to its presence in milk. It could also be present with other mycotoxins that cause harmful synergistic and additive effects to consumers.

Keywords: Ecuador, enzyme-linked immunosorbent assay, raw milk, zearalenone.

\section{Introduction}

Milk production in 2018 reached 864,101 million liters/year worldwide, where $81.4 \%$ was from cattle, with South America ranking fourth place in milk production, accounting for $9.2 \%$ of the world's production. Ecuador ranks fifth in the region [1], reaching 6.65 million liters/day, with a per capita consumption between 90 and $95 \mathrm{~kg} /$ person/year [2].

Zearalenone (ZEA) is a mycotoxin from the fungus Fusarium (fusariotoxins), similar to deoxynivalenol and fumonisins [3]. It affects various types of food worldwide, such as wheat, corn, barley, sorghum, sesame seed, hay, silage, and animal feed [4,5]. ZEA is a lactone resorcyl acid [6] mainly produced by Fusarium graminearum, Fusarium culmorum, and, on a lesser extent, Fusarium equiseti, Fusarium gibbosum, Fusarium oxysporum, and Fusarium moniliforme. Its maximum presence occurs at temperatures between

Copyright: Puga-Torres, et al. Open Access. This article is distributed under the terms of the Creative Commons Attribution 4.0 International License (http://creativecommons.org/licenses/ by/4.0/), which permits unrestricted use, distribution, and reproduction in any medium, provided you give appropriate credit to the original author(s) and the source, provide a link to the Creative Commons license, and indicate if changes were made. The Creative Commons Public Domain Dedication waiver (http:// creativecommons.org/publicdomain/zero/1.0/) applies to the data made available in this article, unless otherwise stated. $20^{\circ} \mathrm{C}$ and $25^{\circ} \mathrm{C}$. If the water activity is higher, there is greater ZEA production [7], so rains can significantly increase ZEA concentrations in wheat. ZEA remains at very low concentrations in the absence of moisture even when severely affected by Fusarium [8].

ZEA can adopt a similar configuration to $17 \beta$-estradiol and other natural estrogens [4]. ZEA undergoes biotransformation by reducing the ketone group of carbon 7 by a hydroxyl group, obtaining $\alpha$-zearalenol $(\alpha-Z E A)[9]$ that is 3-4 times greater than the original compound [10] and $\beta$-zearalenol ( $\beta$-ZEA). There can also be a reduction in the double bond between carbons 11 and 12, forming zearalanone (ZAN) [11]. The affinity and relative power of estrogenicity in descending order are $\alpha$-ZEA, $\alpha$-ZEA ( $\alpha$-ZAN), $\beta$-ZEA, ZAN, ZEA, and $\beta$-ZEA ( $\beta$-ZAN) [12]. Problems in the reproductive function of humans and animals have been reported for ZEA and its metabolites [13]. The maximum permitted levels of ZEA in cow's milk and its derivatives have not been determined despite its high production and consumption worldwide because its elimination in milk is very low [14] due to the molecular weight and lipophilic level of these metabolites [10]. The transformation of ZEA to its metabolites is done in the liver (primarily) and by rumen protozoa [15]. It can then be transferred to raw milk in the forms of ZEA and 
$\alpha$-ZEA [16]. In dairy cows' feed, with three different levels of corn contaminated with ZEA, the conversion rates were $0-0.0075 \%$, not representing a risk due to insignificant transition rates [17]. The microbiota of the rumen, formed by protozoa and bacteria, of healthy bovines constitutes the first line of defense, decreasing mycotoxin contamination of food. In sick animals or when there is excess contamination by mycotoxins in their diets and/or, in turn, dietary changes, minimizing the risk of excretion in milk may be ineffective [10]. There could be alterations in the degradation of this mycotoxin, including the proportion of contaminated concentrated feeds, ruminal fermentation, or associated liver alterations in bile formation and volume [18].

As it is impossible to guarantee a food completely free of mycotoxins [19], different regulations worldwide have established limits between 0.03 and $1 \mathrm{mg} / \mathrm{L}$ ZEA in food in general [20-24]. However, in Ecuador, no maximum limits have been established for ZEA within the Ecuadorian Technical Standards (NTEINEN). There are also no studies of this mycotoxin in raw milk. Therefore, this study aimed to determine its presence in major milk-producing and representative provinces of Ecuador, taking into consideration, its two climatic regions (Andean and coastal regions), times of the year (dry and rainy), types of producer (small, medium, and big), and production systems (extensive, intensive, and mixed).

\section{Materials and Methods}

\section{Ethical approval}

This study did not need contact with animals. So, this study did not require ethical approval.

\section{Study period and area}

The study was conducted from April to November 2019. Due to its natural resources, Ecuador has different milk production systems [25]. The province of Pichincha in North Central Ecuador, one of the most representative regions, represents $\sim 16 \%$ of the country's total milk production and has a temperature between $5^{\circ} \mathrm{C}$ and $20^{\circ} \mathrm{C}, 70-75 \%$ humidity, and $2500-3200 \mathrm{~m}$ above sea level (asl). Manabí follows with $\sim 12 \%$ and has a temperature between $20^{\circ} \mathrm{C}$ and $35^{\circ} \mathrm{C}, 82 \%$ and $90 \%$ humidity, and 150-300 m asl. Santo Domingo de los Tsáchilas represents $\sim 4 \%$ of Ecuadorian production and has a temperature between $21^{\circ} \mathrm{C}$ and $32^{\circ} \mathrm{C}, 80-90 \%$ humidity, and 150-300 $\mathrm{m}$ asl [2,26-28].

The rainy period is between November and May and the dry period is between June and September [29]. ZEA was sampled in these provinces, as they share similar climatic conditions and characteristics (climate, topography, soils, pastures, etc.) to the rest of the milk-producing provinces of Ecuador [26]. Together, they represent more than $30 \%$ of the total production of Ecuadorian milk [2].

\section{Sample collection}

A total of 209 samples were collected in April and November 2019 (rainy season) and June and
August 2019 (dry season), where $72.3 \%$ of the samples were from Pichincha (151 of 209), 22.9\% from Manabí (48 of 209), and 4.8\% from Santo Domingo de los Tsáchilas (10 of 209). Regarding climatic season, $53.1 \%$ were collected during the rainy season (111 of 209) and 46.9\% during the dry season (98 of 209). In April, June, and August 2019, 49 samples $(23.5 \%)$ were taken each month, whereas the remaining $29.7 \%$ (62 of 209) of the samples were taken in November 2019.

Milk samples were collected in an approximate quantity of $100 \mathrm{~mL}$ from bulk tanks on the farms following the provisions of the NTE-INEN-ISO 707: "Milk and dairy products. Guidelines for sampling" [30]. The samples were then transferred to the Milk Quality Control Laboratory of the Faculty of Veterinary Medicine and Zootechnics of the Central University of Ecuador. During transport, a cooler with refrigerants was used to maintain the temperature between $2^{\circ} \mathrm{C}$ and $5^{\circ} \mathrm{C}$ and the samples were then stored at $-20^{\circ} \mathrm{C}$ until the respective analysis.

A survey was carried out among the farmers to stratify them according to (1) province: Pichincha, Manabí, and Santo Domingo de los Tsáchilas; (2) climate region: Andean (cold) or coastal (heat); (3) type of producer: Small, medium, and big (1-20 cows in production, 21-100 animals, and $>100$ cows, respectively); and (4) production systems: Extensive (grazing animals), intensive (stagnant cows), and mixed (grazing and stagnant animals). Independent of the production system, most animals were fed with fresh and concentrated grass and sometimes with silo and hay.

\section{ZEA analysis in milk by enzyme-linked immunosor- bent assay (ELISA)}

All milk samples during each collection month were thawed at room temperature $\left(10-20^{\circ} \mathrm{C}\right)$ and skimmed by centrifugation for $10 \mathrm{~min}$ at $4000 \times \mathrm{g}$. After centrifugation, the upper fat layer was removed, and skim milk was analyzed following the recommended procedure by the test kit MaxSignal ${ }^{\circledR}$ ZEA (ZON) ELISA (Bioo Scientific Corporation, Austin, TX, USA) with a microplate reader Stat Fax 32002260 (Awareness Technology, Inc., Palm City, FL, USA) to $450 \mathrm{~nm}$.

The method was based on a competitive colorimetric ELISA test, where ZEA was covered in the plate wells. After the addition of the substrate, the intensity of the resulting color was inversely proportional to its concentration in the milk. The kit has high cross-reactivity with ZEA (138\%), $\alpha$-ZEA (91\%), and $\alpha$-ZAN (69\%). The limit of detection was as low as $0.000015 \mathrm{mg} / \mathrm{L}$, and the limit of quantification was $0.004 \mathrm{mg} / \mathrm{L}$, with high sensitivity $(0.0001 \mathrm{mg} / \mathrm{L})$ and high reproducibility. It has a specificity (cross-reactivity) of $100 \%$ (ZEA), $138 \%$ (ZAN), 91\% ( $\alpha$-ZEA), $21 \%(\beta$-ZEA), $69 \%(\alpha-Z A N)$, and $6 \%(\beta-Z A N)$. It also includes standard solutions of $0,0.1,0.25,0.5$, $1.5,4.5$, and $0.025 \mathrm{mg} / \mathrm{L}$ used to generate regression 
curves between ZEA concentration and optical density.

For the test, a $20 \mu \mathrm{L}$ skim milk sample was diluted with 35\% methanol (Merck, Darmstadt, Germany), with a dilution factor of 1:10. All reagents were kept at $10-20^{\circ} \mathrm{C}$ until use and homogenized by slow inversion. The procedure used a $1 \mathrm{X}$ wash solution. For the ZEA antibody mix, 1 volume of the ZEA antibody was mixed with 1 volume of the antibody conjugate (horseradish peroxidase [HRP] \#2). This mixture was used within 5 min after its preparation, as a longer storage time can result in lower detection values.

All analyses were performed in duplicate to achieve a sufficient number of samples, calculate the standard deviation and coefficient of variation, and validate the data. Initially, $50 \mu \mathrm{L}$ of each ZEA standard were added, depending on the kit, in different wells in ascending order, that is, from low concentration to high concentration. In the following wells, $50 \mu \mathrm{L}$ of each sample were added followed by $100 \mu \mathrm{L}$ ZEA-HRP conjugate to all wells using a multichannel pipette. The well solutions were homogenized manually by gentle plate movements for $1 \mathrm{~min}$. After incubating the plate at $10-20^{\circ} \mathrm{C}$ for $30 \mathrm{~min}$, the solution was completely decanted from the wells, and the liquid was desiccated. The plate was washed three times with $300 \mu \mathrm{L}$ of $1 \times$ wash solution. After the last wash, the plate was inverted and gently tapped on paper towels. A $100 \mu \mathrm{L}$ TMB substrate was added to each well. The plate was gently mixed for $1 \mathrm{~min}$ and incubated at $10-20^{\circ} \mathrm{C}$ for $15 \mathrm{~min}$, covering the plate with adhesive. A $100 \mu \mathrm{L}$ solution was finally placed as a stop buffer to stop the enzyme reaction. The bottom of the plate was wiped with a cloth to avoid moisture or fingerprints that might interfere with the readings and was immediately read on the plate reader with a $450 \mathrm{~nm}$ wavelength.

To design the standard curve based on the average relative absorbance (\%), the following formula can be used, derived from each reference standard based on its concentration $(\mathrm{ng} / \mathrm{mL})$ on a logarithmic curve: Relative absorbance $(\%)=($ standard absorbance or sample $\times 100$ /zero standard absorbance). With the mean relative absorbance values for each sample, the concentration of each mycotoxin was determined from the standard curve. However, to obtain the calibration curve, the ELISA analysis program MaxSignal ${ }^{\circledR}$ in Excel was used.

\section{Statistical analysis}

All results were expressed as the mean, minimum, and maximum concentrations of ZEA. The Shapiro-Wilk test $(\mathrm{p}<0.05)$ was performed to confirm the normality of the data, resulting in an extremely low $\mathrm{p}=2.2 \mathrm{e}^{-16} \quad(\mathrm{p} \leq 0.05)$; therefore, non-parametric tests were used [31]. The differences in ZEA concentrations were analyzed in terms of cantons, provinces, types of producers, production systems, and sampling months by the Kruskal-Wallis test, whereas the time and climatic region were analyzed by the Wilcoxon test. When there were significant differences in the Kruskal-Wallis test, a post hoc analysis was performed using the Mann-Whitney U-test on each pair of groups using a Bonferroni correction to decrease the probability of incurring error type I. The free statistical software RStudio version 1.2.5019 (RStudio, Inc., Boston, MA, USA) was used with a level of statistical significance of $p<0.05$.

\section{Results}

At the end of the investigation, 99.5\% (208 of 209) of the raw milk samples analyzed were positive for ZEA, but all milk samples analyzed were below the maximum limits allowed by different food regulations, ranging between 0.03 and $1 \mathrm{mg} / \mathrm{L}$ [20-24]. Only one sample was under the detection limit (UDL).

Tables- 1 and 2 and Figure-1 show the results obtained by cantons, provinces, months, climatic regions, climatic seasons, types of producer, and production systems. By cantons, the mean was $0.0015 \mathrm{mg} / \mathrm{L}$ and the maximum was $0.0102 \mathrm{mg} / \mathrm{L}$

Table-1: Minimum, mean, and maximum values of ZEA obtained by cantons, provinces, and climatic regions ( $\mathrm{n}=209)$.

\begin{tabular}{|c|c|c|c|c|c|}
\hline \multicolumn{2}{|l|}{ Variable } & \multirow[t]{2}{*}{ Minimum (mg/L) } & \multirow[t]{2}{*}{ Mean $(\mathrm{mg} / \mathrm{L})$} & \multirow[t]{2}{*}{ Maximum (mg/L) } & \multirow[t]{2}{*}{ SD (mg/L) } \\
\hline Canton & & & & & \\
\hline Mejía & Pichincha & 0.0008 & 0.0015 & 0.0021 & 0.0010 \\
\hline Quito & Pichincha & 0.0008 & 0.0016 & 0.0036 & 0.0011 \\
\hline Cayambe & Pichincha & 0.0005 & 0.0015 & 0.0032 & 0.0010 \\
\hline Pedro Moncayo & Pichincha & 0.0009 & 0.0018 & 0.0042 & 0.0011 \\
\hline Rumiñahui & Pichincha & 0.0009 & 0.0014 & 0.0027 & 0.0011 \\
\hline Chone & Manabí & UDL & 0.0020 & 0.0102 & 0.0011 \\
\hline El Carmen & Manabí & 0.0003 & 0.0014 & 0.0025 & 0.0010 \\
\hline Alluriquín & Santo Domingo de los Tsáchilas & 0.0010 & 0.0016 & 0.0035 & 0.0007 \\
\hline \multicolumn{6}{|l|}{ Province } \\
\hline Pichincha & & 0.0005 & 0.0014 & 0.0042 & 0.0009 \\
\hline Manabí & & UDL & 0.0016 & 0.0102 & 0.0011 \\
\hline Santo Domingo & de los Tsáchilas & 0.0010 & 0.0016 & 0.0035 & 0.0007 \\
\hline \multicolumn{6}{|c|}{ Climatic region } \\
\hline Coastal & & UDL & 0.0016 & 0.0102 & 0.0011 \\
\hline Inter-Andean & & 0.0005 & 0.0014 & 0.0042 & 0.0009 \\
\hline
\end{tabular}

SD $=$ Standard deviation, UDL=Under the detection limit

Veterinary World, EISSN: 2231-0916 


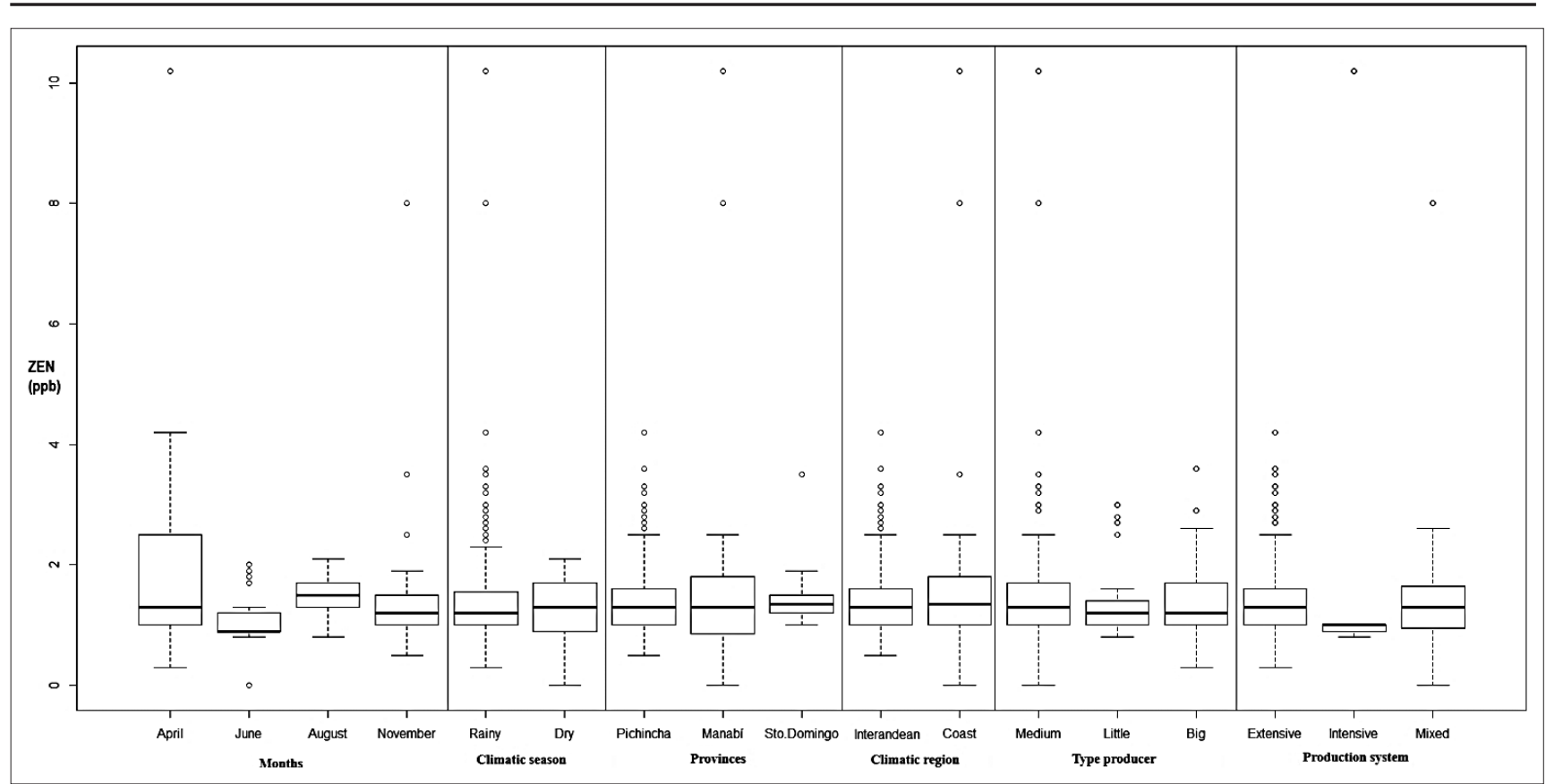

Figure-1: Boxplot with values according to months, climatic seasons, provinces, climatic regions, types of producer, and production systems.

Table-2: Minimum, mean, and maximum values of ZEA obtained by months, climatic seasons, types of producer, and production systems $(n=209)$.

\begin{tabular}{|c|c|c|c|c|}
\hline \multirow{2}{*}{$\begin{array}{l}\text { Variable } \\
\text { Month }\end{array}$} & \multirow[t]{2}{*}{$\begin{array}{c}\text { Minimum } \\
(\mathrm{mg} / \mathrm{L})\end{array}$} & \multirow[t]{2}{*}{$\begin{array}{l}\text { Mean } \\
(\mathrm{mg} / \mathrm{L})\end{array}$} & \multicolumn{2}{|c|}{$\begin{array}{l}\text { Maximum SD }(\mathrm{mg} / \mathrm{L}) \\
(\mathrm{mg} / \mathrm{L})\end{array}$} \\
\hline & & & & \\
\hline April & 0.0003 & 0.0019 & 0.0102 & 0.0011 \\
\hline June & UDL & 0.0011 & 0.0020 & 0.0004 \\
\hline August & 0.0008 & 0.0015 & 0.0021 & 0.0009 \\
\hline November & 0.0005 & 0.0014 & 0.0080 & 0.0009 \\
\hline \multicolumn{5}{|c|}{ Climatic season } \\
\hline Rainy & 0.0003 & 0.0016 & 0.0102 & 0.0010 \\
\hline Dry & UDL & 0.0014 & 0.0080 & 0.0011 \\
\hline \multicolumn{5}{|c|}{ Type of producer } \\
\hline Small & 0.0008 & 0.0014 & 0.0030 & 0.0010 \\
\hline Medium & UDL & 0.0015 & 0.0102 & 0.0010 \\
\hline Big & 0.0003 & 0.0014 & 0.0036 & 0.0010 \\
\hline \multicolumn{5}{|c|}{ Production system } \\
\hline Extensive & 0.0003 & 0.0014 & 0.0040 & 0.0010 \\
\hline Intensive & 0.0008 & 0.0028 & 0.0102 & 0.0011 \\
\hline Mixed & UDL & 0.0015 & 0.0080 & 0.0010 \\
\hline
\end{tabular}

$\mathrm{SD}=$ Standard deviation, $\mathrm{UDL}=$ Under the detection limit

(Table-1), both from Chone Canton of Manabí. By provinces, where the maximum value was $0.0102 \mathrm{mg} / \mathrm{L}$, where two were from Manabí. The lowest mean $(0.0014 \mathrm{mg} / \mathrm{L})$ was from Pichincha, whereas the highest mean $(0.0016 \mathrm{mg} / \mathrm{L})$ was from Manabí and Santo Domingo de los Tsáchilas (Table-1). By cantons and provinces, the p-value was 0.5683 and 0.6541 , respectively $(\mathrm{p} \geq 0.05)$, without significant differences between the cantons and provinces. By climatic region, the maximum value was $0.0102 \mathrm{mg} / \mathrm{L}$, both from the coastal region. The lowest mean $(0.0014 \mathrm{mg} / \mathrm{L})$ corresponded to the sierra region, whereas the largest $(0.0016 \mathrm{mg} / \mathrm{L})$ was from the coastal region (Table-1). The $p$-value was $0.8426(p \geq 0.05)$, without significant differences between the climatic regions.
Based on the results per month (Table-2), the UDL value corresponded to June, whereas the maximum $(0.0102 \mathrm{mg} / \mathrm{L})$ was in April. The lowest mean $(0.0011 \mathrm{mg} / \mathrm{L})$ was found in June, and the highest mean $(0.0019 \mathrm{mg} / \mathrm{L})$ was found in April. The p-value was $2.253 \mathrm{e}^{-07}(\mathrm{p} \leq 0.05)$, with significant differences between April and June, between June and August, between June and November, and between August and November.

By climatic season, the UDL value corresponded to the dry season, and the maximum $(0.0102 \mathrm{mg} / \mathrm{L})$ corresponded to the rainy season (Table-2). The lowest mean $(0.0014 \mathrm{mg} / \mathrm{L})$ corresponded to the dry season, and the highest mean $(0.0016 \mathrm{mg} / \mathrm{L})$ corresponded to the rainy season. The $p$-value obtained was $0.4469(p \geq 0.05)$, without significant differences between the climatic seasons.

By types of producer (Table-2), the UDL value and the maximum $(0.0102 \mathrm{mg} / \mathrm{L})$ were from the medium producers. The lowest mean $(0.0014 \mathrm{mg} / \mathrm{L})$ was from the large producers, whereas the highest mean $(0.0015 \mathrm{mg} / \mathrm{L})$ was from medium producers. The $p$-value was $0.8225(\mathrm{p} \geq 0.05)$, without significant differences between the types of producers.

By production systems (Table-2), the UDL value corresponded to the mixed type, whereas the maximum value $(0.0102 \mathrm{mg} / \mathrm{L})$ corresponded to the intensive type. The lowest mean $(0.0014 \mathrm{mg} / \mathrm{L})$ corresponded to the extensive type, and the highest $(0.0028 \mathrm{mg} / \mathrm{L})$ corresponded to the intensive type. The $p$-value was $0.4368(p \geq 0.05)$, without significant differences between the production systems.

\section{Discussion}

There are no reports of ZEA determination in raw milk from Ecuador, so this research is the pioneer. The mycotoxin was found in $99.5 \%$ (208 of 209) of the raw 
milk samples, with a mean of $0.0015 \mathrm{mg} / \mathrm{L}$. The results showed much higher values than those found in various studies. For example, in China, the presence of ZEA was determined only in $23.3 \%$ of the raw milk samples, $16.7 \%$ in pasteurized milk, and $25 \%$ in milk powder of several dairy farms and different supermarkets in Beijing [32]. In Monte Carlo milk, ZEA was determined at a mean of $0.00039 \mathrm{mg} / \mathrm{L}$ and was associated with other mycotoxins. ZEA was also detected in $9 \%$ of 185 cow's milk-based infant formulas [33], with corn as the main source [34]. In Argentina, ZEA was determined at the concentration of $0.0013 \mathrm{mg} / \mathrm{L}$ in raw milk, where corn silage and balanced feed are the largest mycotoxin reservoirs [35]. In Portugal, ZEA was found in 100\% of the milk samples from a dairy farm [36]. In all cases, these values were below the mean of this study.

In Turkish breast milk, ZEA was also determined at a mean of $0.0002 \mathrm{mg} / \mathrm{L}$ [37]. In infant formulas of four different brands from Italy, ZEA was determined in $9 \%$ (7 of 185) of the samples, with a maximum value of $0.0008 \mathrm{mg} / \mathrm{L} ; \alpha-Z E A$ was determined in $26 \%$ ( 9 of 185), with a maximum value of $0.0129 \mathrm{mg} / \mathrm{L}$; and $\beta$-ZEA was determined in $28 \%$ (53 of 185), with a maximum value of $0.0732 \mathrm{mg} / \mathrm{L}$. No $\alpha-Z A N$ or $\beta$-ZAN was found [33].

More studies are needed to assess the importance of milk and derivatives as a source of estrogen for humans [38]. Although ZEA is not directly carcinogenic [10], it has disruptive effects on hormonal balance due to its similarity to natural estrogens $[39,40]$ and may cause reproductive system diseases, including prostate, ovary, cervix, and breast cancers [41]. ZEA is also toxic to liver cells [42], ZEA can also affect the development of gamete and embryogenesis in humans and animals [43] and lead to precocious puberty in girls, fertility disorders and reproduction in women [44], testosterone reduction, spermatogenesis, and even feminization in men [45], causing damage to germ cells and testicular structure [43].

ZEA can bioaccumulate in the body [41]. On its own, ZEA can cause oxidative stress in the small intestine, ileum, and mesenteric lymph nodes [46]. However, when combined with several mycotoxins, ZEA causes major problems in intestinal function [47] and cytotoxicity in human Caco-2 cells [48]. In milk, ZEA is frequently found together with ochratoxin $\mathrm{A}$ or aflatoxin M1 (AFM1) [49]. This is important because, in a parallel study, AFM1 was found in the same raw milk in $100 \%$ of the samples, with a mean of $0.0774 \mu \mathrm{g} / \mathrm{kg}$ [50].

Therefore, it is necessary to take appropriate measures to reduce risks to human and animal health $[51,52]$. Because mycotoxins present in raw milk are very stable and heat treatments, such as pasteurization, cannot remove them [53], it is only useful with high temperatures between $237^{\circ} \mathrm{C}$ and $306^{\circ} \mathrm{C}$ (but the organoleptic characteristics of milk are lost). Different techniques to remove mycotoxins in food are classified into (1) physical (microwave, extrusion, heating, ultraviolet light, gamma radiation, and adsorption agents, such as bentonite and aluminosilicates), (2) chemical (oxidants, such as ozone and hydrogen peroxide, and hydrolases, such as aldehydes, acids, and bases), and (3) biological (enzymes of microorganisms, lactic acid bacteria, yeasts, etc.) [54]. One of the widely used techniques is the addition of an antimycotoxin additive to the diet of dairy cows, which can prevent many harmful effects on animals [55].

Modern methods include obtaining cell-free supernatants from whey after fermentation by kefir granules (CIDCA AGK1) that act on the growth of $F$. graminearum and the consequent production of ZEN [56] and the biocatalyst from Gliocladium roseum (ZENG) with a high degradation performance toward ZEN and its toxic derivatives $\alpha$-ZEA and $\alpha$-ZAN [57]. Lactobacillus kefiri (KFLM), Kazachstania servazzii (KFGY7), and Acetobacter syzygii strains are also used. When consumed together with kefir, they reduce the gastrointestinal absorption of mycotoxins [58].

\section{Conclusion}

This investigation is the first to detect ZEA in raw milk from Ecuador. All raw milk samples analyzed had ZEA levels (with a mean of $0.0015 \mathrm{mg} / \mathrm{L}$ ) below those allowed by national and international regulatory organizations. Therefore, its presence does not constitute a threat to public health. However, much attention should be paid, and more research is needed, as $99.5 \%$ of the samples had levels of this mycotoxin. ZEA may be present with other mycotoxins in milk that cause harmful synergistic and additive effects to consumers.

\section{Authors' Contributions}

BP and CG: Designed the study, wrote the manuscript, and participated in conducting the experiment. BP, MC, and DA: Collected the samples. BP, MC, and DA: Processed and analyzed the data. All authors read and approved the final manuscript.

\section{Acknowledgments}

We thank Mr. Santiago Gordillo, Santiago Miranda, Wilson Espín, and Enrique Navarrete for their help with the collection of raw milk samples. This work was financially supported by the General Directorate of Research of the Central University of Ecuador (Grant: DOCT-DI-2018-21).

\section{Competing Interests}

The authors declare that they have no competing interests.

\section{Publisher's Note}

Veterinary World remains neutral with regard to jurisdictional claims in published institutional affiliation.

\section{References}

1. OCLA. (2019) Lechería Mundial-Principales Aspectos. Available from: http://www.ocla.org.ar/contents/newschart/ 
portfolio/?categoryid=8. Retrieved on 28-12-2020.

2. INEC. (2020) Encuesta de Superficie y Producción Agropecuaria Continua. https://www.ecuadorencifras. gob.ec/documentos/web-inec/Estadisticas_agropecuarias/ espac/espac-2019/Presentacion de los principales resultados ESPAC 2019.pdf. Retrieved on 05-01-2021.

3. Travel, A., Metayer, J.P., Mika, A., Bailly, J.-D., Cleva, D., Boissieu, C., Le Guennec, J., Albaric, O., Labrut, S., Lepivert, G., and Marengue, E. (2019) Toxicity of fumonisins, deoxynivalenol, and zearalenone alone and in combination in Turkeys fed with the maximum European union-tolerated level. Avian Dis., 63(4): 703-712.

4. Gimeno, A. and Martins, M.L. (2011) Micotoxinas y Micotoxicosis En Animales y Humanos. $1^{\text {st }}$ ed. TerceraEdi., Special Nutrients, Miami, USA.

5. Duarte-Vogel, S. and Villamil-Jiménez, L.C. (2006) Micotoxinas En La Salud Pública. Rev. Salud Pública (Bogota). 8(1): 129-135.

6. Dänicke, S. and Winkler, J. (2015) Invited review: Diagnosis of zearalenone (ZEN) exposure of farm animals and transfer of its residues into edible tissues (carry over). Food Chem. Toxicol., 84(1): 225-249.

7. del Castillo, J.M.S. (2007) Micotoxinas En Alimentos. Ediciones Díaz de Santos, Valencia, España.

8. Kharbikar, L.L., Dickin, E.T. and Edwards, S.G. (2015) Impact of post-anthesis rainfall, fungicide and harvesting time on the concentration of deoxynivalenol and zearalenone in wheat. Food Addit. Contam., 32(12): 2075-2085.

9. Gholamreza, K. and Soghra, M. (2014) Mycotoxins. In: Food Toxicology: Current Advances and Future Challenges. Apple Academic Press, Boston, Massachusetts. p179-198.

10. Becker-Algeri, T.A., Castagnaro, D., de Bortoli, K., de Souza, C. and Drunkler, D.A. (2016) Mycotoxins in bovine milk and dairy products: A review. J. Food Sci., 81(3): 544-552.

11. Pleadin, J. (2015) Mycotoxins in grains and feed contamination and toxic effect in animals. Biotechnol. Anim. Husbandry, 31(4): 441-456.

12. Steinkellner, H., Binaglia, M., Dall'Asta, C., Gutleb, A.C., Metzler, M., Oswald, I.P., Parent-Massin, D., and Alexander, J. (2019) Combined hazard assessment of mycotoxins and their modified forms applying relative potency factors: Zearalenone and T2/HT2 toxin. Food Chem. Toxicol., 131(1): 110599.

13. Li, P., Su, R., Yin, R., Lai, D., Wang, M., Liu, Y. and Zhou, L. (2020) Detoxification of mycotoxins through biotransformation. Toxins, 12(2): 121.

14. Prelusky, D., Scott, P., Trenholm, H. and Lawrance, G. (1990) Minimal transmission of zearalenone to milk of dairy cows. J. Environ. Sci. Health Part B, 25(1): 87-103.

15. Malekinejad, H., Maas-Bakker, R. and Fink-Gremmels, J. (2006) Species differences in the hepatic biotransformation of zearalenone. Vet. J., 172(1): 96-102.

16. Bullerman, L.B. and Bianchini, A. (2007) Stability of mycotoxins during food processing. Int. J. Food Microbiol., 119(1-2): 140-146.

17. Winkler, J., Kersten, S., Valenta, H., Meyer, U., Engelhardt, U.H. and Dänicke, S. (2015) Development of a multi-toxin method for investigating the carryover of zearalenone, deoxynivalenol and their metabolites into milk of dairy cows. Food Addit. Contam., 32(3): 371-380.

18. Dänicke, S., Keese, C., Meyer, U., Starke, A., Rehage, J., Dänicke, S., Keese, C., Meyer, U. and Starke, A. (2014) Zearalenone (ZEN) metabolism and residue concentrations in physiological specimens of dairy cows exposed longterm to ZEN-contaminated diets differing in concentrate feed proportions. Arch. Anim. Nutr., 68(6): 492-506.

19. Pereira, C.S., Cunha, S.C. and Fernandes, J.O. (2019) Prevalent mycotoxins in animal feed: Occurrence and analytical methods. Toxins, 11(5): 290.

20. Codex-Alimentarius. Documento de Posición sobre Zearalenona. Available from: http://www.fao.org/tempref/
codex/Meetings/CCFAC/ccfac31/FA99_15S.pdf. Retrieved on 12-01-2021.

21. European-Commission. (2006) Commission regulation (EC) no 1881/2006 setting maximun levels for certain contaminants in foodstuffs. Off. J. Eur. Union, 364(1): 5-24.

22. EFSA. (2011) Scientific opinion on the risks for public health related to the presence of zearalenone in food. EFSA J., 9(6): 2197.

23. EFSA. (2016) Appropriateness to set a group health-based guidance value for zearalenone and its modified forms. EFSA J., 14(4): 46.

24. FAO. (2003) Reglamentos a Nivel Mundial Para Las Micotoxinas en Los Alimentos y en Las Raciones en el año 2003. Avaialble from: http://www.fao.org/3/a-y5499s.pdf. Retrieved on 16-01-2021.

25. Contero, R., Aquino, E.L., Simbaña, P.E. and Bueno, R. (2019) A study in ecuador of the calibration curve for total bacterial count by flow cytometry of raw bovine milk. $L a$ Granja Rev. Cienc. Vida, 29(1): 97-104.

26. CIL. (2015) La Leche Del Ecuador Historia de La Lechería Ecuatoriana. Centro de la Industria Láctea, Quito-Ecuador, Ecuador.

27. CIL. (2019) Datos del Sector Lácteo-Ecuador. Available from: https://www.e152f73b-81b4-4206-a6ee8b984b6a13b0.filesusr.com/ugd/6cc8de_513a9bb8db76451a9a74586d7902bb3b.pdf. retrieved on 19-01-2021.

28. Brassel, F. and Hidalgo, F. (2007) Libre Comercio y Lácteos (La Producción de la Leche en el Ecuador Entre el Mercado Nacional y la Globalización). SIPAE.

29. INAMHI. (2016) Climas del Ecuador. Available from: http://www.serviciometeorologico.gob.ec/gisweb/tipo de climas/pdf/climas del Ecuador 2016.pdf. Retrieved on 24-01-2021.

30. INEN. (2014) Leche y Productos Lácteos. Directrices Para La Toma de Muestras (ISO 707:2008, IDT). Quito-Ecuador, p1-49.

31. De La Rosa, A.C. and Labrada, V. (2014) Bioestadística. Editorial El Manual Moderno, México DF.

32. Huang, L.C., Zheng, N., Zheng, B.Q., Wen, F., Cheng, J.B., Han, R.W., Xu, X.M., Li, S.L. and Wang, J.Q. (2014) Simultaneous determination of aflatoxin M1, ochratoxin A, zearalenone and $\alpha$-zearalenol in milk by UHPLC-MS/MS. Food Chem., 146(1): 242-249.

33. Meucci, V., Soldani, G., Razzuoli, E., Saggese, G. and Massart, F. (2011) Mycoestrogen pollution of Italian infant. Food. J. Pediatr., 159(2): 278-283.

34. Coffey, R., Cummins, E. and Ward, S. (2009) Exposure assessment of mycotoxins in dairy milk. Food Control, 20(3): 239-249.

35. Signorini, M.L., Gaggiotti, M., Molineri, A., Chiericatti, C.A., de Basílico, M.L.Z., Basílico, J.C. and Pisani, M. (2012) Exposure assessment of mycotoxins in cow's milk in Argentina. Food Chem. Toxicol., 50(2): 250-257.

36. Viegas, S., Assunção, R., Twarużek, M., Kosicki, R., Grajewski, J. and Viegas, C. (2019) Mycotoxins feed contamination in a dairy farm potential implications for milk contamination and workers' exposure in a one health approach. J. Sci. Food Agric., 100(3): 1118-1123.

37. Dinleyici, M., Aydemir, O., Yildirim, G.K., Kaya, T.B. and Carman, K.B. (2018) Human mature milk zearalenone and deoxynivalenol levels in Turkey. Neuro Endocrinol. Lett., 39(4): 325-330.

38. Stypuła-Tr, S., Minta, M., Radko, L. and Zmudzki, J. (2015) Application of the yeast-based reporter gene bioassay for the assessment of estrogenic activity in cow's milk from Poland. Environ. Toxicol. Pharmacol., 40(3): 876-885.

39. Jocsak, G., Ioja, E., Kiss, D.S., Toth, I., Barany, Z., Bartha, T., Frenyo, L.V. and Zsarnovszky, A. (2019) Endocrine disruptors induced distinct expression of thyroid and estrogen receptors in rat versus mouse primary cerebellar cell cultures. Brain Sci., 9(12): 1-19.

40. Kowalska, K., Habrowska-Górczyńska, D.E. and 
Piastowska-Ciesielska, A.W. (2016) Zearalenone as an endocrine disruptor in humans. Environ. Toxicol. Pharmacol., 48: 141-149.

41. Rogowska, A., Pomastowski, P., Sagandykova, G. and Buszewski, B. (2019) Zearalenone and its metabolites: Effect on human health, metabolism and neutralisation methods. Toxicon, 162: 46-56.

42. Yoon, J.E., Lee, K.Y., Seok, J.S., Cheng, W.N. and Kwon, H.C. (2020) Zearalenone induces endoplasmic reticulum stress and modulates the expression of phase I/II enzymes in human liver cells. Toxins, 12(1): 1-15.

43. Yang, D., Jiang, X., Sun, J., Li, X., Li, X., Jiao, R., Peng, Z., Li, Y. and Bai, W. (2018) Toxic effects of zearalenone on gametogenesis and embryonic development: A molecular point of review. Food Chem. Toxicol., 119: 24-30.

44. ELIKA. (2019) FV Para la SA Zearalenona. Available from: http://www.elika.net/datos/pdfs_agrupados/documento19/ zea web.pdf. Retrieved on 31-01-2021.

45. Cao, H., Zhi, Y., Xu, H., Fang, H. and Jia, X. (2019) Zearalenone causes embryotoxicity and induces oxidative stress and apoptosis in differentiated human embryonic stem cells. Toxicol. In Vitro., 54: 243-250.

46. Cheng, Q., Jiang, S., Huang, L., Wang, Y., Yang, W., Yang, Z. and Ge, J. (2020) Effects of zearalenone-induced oxidative stress and keap1-Nrf2 signaling pathway-related gene expression in the ileum and mesenteric lymph nodes of post-weaning gilts. Toxicology, 429: 152337.

47. Wu, C., Gao, Y., Li, S., Huang, X., Bao, X., Wang, J. and Zheng, N. (2019) Modulation of intestinal epithelial permeability and mucin MRNA (MUC2, MUC5AC, and MUC5B) expression and protein secretion in Caco-2/HT29MTX Co-cultures exposed to aflatoxin M1, ochratoxin A, and zearalenone individually or collectively. Toxicol. Lett., 309(1): 1-9.

48. Gao, Y.N., Wang, J.Q., Li, S.L., Zhang, Y.D. and Zheng, N. (2016) Aflatoxin M1 cytotoxicity against human intestinal Caco-2 cells is enhanced in the presence of other mycotoxins. Food Chem. Toxicol., 96: 79-89.
49. Zheng, N., Gao, Y.N., Liu, J., Wang, H.W. and Wang, J.Q. (2018) Individual and combined cytotoxicity assessment of zearalenone with ochratoxin A or $\alpha$-zearalenol by full factorial design. Food Sci. Biotechnol., 27(1): 251-259.

50. Puga-Torres, B., Salazar, D., Cachiguango, M., Cisneros, G. and Gómez-Bravo, C. (2020) Determination of aflatoxin M1 in raw milk from different provinces of ecuador. Toxins, 12(8): 498.

51. Ismail, Z.B., Al-Nabulsi, F., Abu-Basha, E. and Hananeh, W. (2020) Occurrence of on-farm risk factors and health effects of mycotoxins in dairy farms in Jordan. Trop. Anim. Health Prod., 52(5): 2371-2377.

52. Santini, A., Raiola, A., Ferrantelli, V., Giangrosso, G., Macaluso, A., Bognanno, M., Galvano, F. and Ritieni, A. (2013) Aflatoxin M 1 in raw, UHT milk and dairy products in Sicily (Italy). Food Addit. Contam. Part B, 6(3): 181-186.

53. Ketney, O., Santini, A. and Oancea, S. (2017) Recent aflatoxin survey data in milk and milk products: A review. Int. J. Dairy Technol., 70(3): 320-331.

54. Nazhand, A., Durazzo, A., Lucarini, M., Souto, E.B. and Santini, A. (2020) Characteristics, occurrence, detection and detoxification of aflatoxins in foods and feeds. Foods, 9(5): 644.

55. Jovaisiene, J., Bakutis, B., Baliukoniene, V. and Gerulis, G. (2016) Fusarium and Aspergillus mycotoxins effects on dairy cow health, performance and the efficacy of antimycotoxin additive. Pol. J. Vet. Sci., 19(1): 79-87.

56. Gamba, R.R., De Antoni, G. and Peláez, A.L. (2016) Whey permeate fermented with kefir grains shows antifungal effect against Fusarium graminearum. J. Dairy Res., 83(2): 249-255.

57. Zhang, Z., Xu, W., Wu, H., Zhang, W. and Mu, W. (2019) Identification of a potent enzyme for the detoxification of zearalenone. J. Agric. Food Chem., 68: 376-383.

58. Ben, F., Fedhila, K., Chaieb, K., Kouidhi, B., Bakhrouf, A. and Abrunhosa, L. (2017) Adsorption of aflatoxin B1, zearalenone and ochratoxin A by microorganisms isolated from kefir grains. Int. J. Food Microbiol., 251: 1-7. 